\title{
Персонажи Библии в словацких сравнениях (на фоне других языков)*
}

\author{
И. В. КУЗНЕЦОВА \\ Кафедра педагогики и методики начального образования, Чувашский государственный \\ педагогический университет, ул. К. Маркса, д. 38, RU-428000 Чебоксары \\ E-mail: irinak47@yandex.ru
}

(Received: 15 February 2016; accepted: 8 April 2016)

\begin{abstract}
This paper deals with the presentation of Slovak biblical similes in dictionaries and their usage by native speakers. Some of the examples are complemented with etymological commentaries.
\end{abstract}

Keywords: phraseology, biblical characters, Slovak similes, phraseography, etymology

Многие сотни речений Священного Писания стали принадлежностью фразеологии христиан. В фонде библейской фразеологии много выражений, прямо или косвенно восходящих к Книге книг и апокрифическим (неканоническим) текстам. Причем «из блока интернациональных фразеологизмов библеизмы исследованы более других единиц - и в разных аспектах: с точки зрения привязки к исходным текстам Писания, процессов исторического формирования их современных значений и выражаемых ими смыслов в сегодняшнем художественном и публицистическом контексте» (СЕливеРСтовА 2013: 235).

Значимость Библии в жизни христиан, обращающихся во многих жизненных ситуациях к ее заповедям, мотивировала появление таких оборотов, как verit' niečomu, niekomu ako písmu [svätému] (Písmu svätému, evanjeliu) ${ }^{1}$ 'свято, безгранично верить' (VSRS 1: 486, VSRS 3: 103); poznat' ako Písmo sväté ' ‘знать досконально, наизусть' (СклАдАнА 1995: 67). Древность книги

* Работа выполнена при финансовой поддержке Российского научного гуманитарного фонда. Проект «Ключевые концепты русских народных сравнений (опыт идеографического словаря)» (№ 14-04-00090/14; шифр ИАС 31.16.571.2014).

${ }^{1}$ Фразеологизм есть и в других языках: рус. верить в кого как в Евангелие (И. М. Долгоруков: Повесть о рождении моем, происхождении и всей моей жизни..., 1788-1822); верить / поверить как Слову Божьему (Ф. М. Достоевский: Бесы, 1871-1872; Н. Н. Евреинов: Тайна Распутина, 1924); верить кому, чему как Священному Писанию (Евангелию) (MOKIENKO-WuRM 2002: 135); чеш. věřit komu, čemu jako Písmu svatému (písmu, slovu božímu, svatýmu evandělium, evangeliu) (ZAORÁLEK 2000: 509, 527, 442; MOKIENKO-WURM 2002: 135, 380); brát co jako slovo boži (MOKIENKO-WURM 2002: 476); польск., кашуб. wierzeć w co jak w Ewangelię (SKORUPKA 1: 216, TREDER 1989: 144).

${ }^{2}$ Cр. рус. знать что как Библию (КузнЕцовА 1995: 41); лемк. знати як біблію (ВАРХОЛІВчЕНКО 1990: 20). 
дала жизнь устойчивому сравнению starý ako Biblia' 'о старом человеке' (FINK 2006: 150), а ее язык - компаративизму hovorit' ako slová boží 4 'говорить мудро, рассудительно’ (SKLADANÁ 1993: 91).

В словацком языке среди фразеобиблеизмов-интернационализмов немало оборотов с компаративной структурой: citit'sa (žit', žit'si, mat'sa) ako v raji 'чуувствовать себя (жить и т. п.) счастливо, беззаботно, в полном достатке и благополучии' (KSSJ 2003: 608, RSFS 1998: 586); Tolko je toho ako hviezd na nebi ' 'о неисчислимо большом количестве' (ZÁTURECKÝ 2005: 561); malý ako horčičné zrnko 'о чем-л. чрезвычайно малом, незначительном по размерам' (MАтоLÁKOVÁ 2013); chránit' (opatrovat', strážit') ako zrenicu [svojho] oka ${ }^{8}$ 'тщательно, заботливо беречь' (ZÁTURECKÝ 2005: 156, SMIEŠKOVÁ 1974:

${ }^{3}$ Серб. стар као библија (РСХКЈ 1: 195); болг. стар като Библията; макед. стар како Библија; хорв. star kao (ko) biblija (Biblija) (Fink 2006: 150, MenaC-Minalić 2005: 312); cp. также с рус. диал. жизнь чья что Библия 'о чьей-л. излишне затянувшейся, слишком долгой жизни' (шутл.) (СРНГ 34: 285); серб. то је старо као библија 'о какой-л. извечной, неизменной, не теряющей своей жизненности истине, принципе, характерной особенности, чувстве и т. п.' (РСXC 1988: 822).

${ }^{4}$ Чеш. mluvit jako bible (evangelium, Písmo svaté) 'говорить легко, красиво, как по писаному; доходчиво, красноречиво' (SČF 1983: 42, MOKIENKO-WURM 2002: 36, 135); укр. говорити як з євангелія 'говорить доходчиво, умело поясняя' (ЮрченКо-ІвченКо 1993: 53).

${ }^{5}$ Рус. чувствовать себя (жить) как в раю (ОГОЛЬЦЕв 2001: 535); житье как в раю (ДАЛь 1: 125); диал. боговать ['жить обеспеченно, не испытывая нужды'] как в раю (СОГ 1989: 81); укр. жити як у раю (ЮРЧЕНКО-ІВЧЕНКО 1993: 125); лемк. жыті як у раю (ВАРХОЛ-ІВЧЕНКО 1990: 89, 111); бел. жыць як у раі (СБНП 2011: 347); болг. живея като в рая (НБФР 2: 133); серб. жсивети као у раjy; в.-луж. dobro so méć kaž w njebjeskim raju (RADYSERB-WJELA 1902: 240); хорв. živjeti kao u raju (БИРих 1998: 23); чеш. cítit se (žít, být, mít se, je tam) jako v ráji (SČF 1983: 431, 299; ZAORÁLEK 2000: 491, 518); польск. czuć się jak w raju (SKORUPKA 2: 8); кашуб. miec sę (z̈̈̈c, biło nam) jak w raju (TREDER 1989: 135).

${ }^{6}$ Сравнение восходит к строкам Книги книг: «И потому от одного, и притом омертвелого, родилось так много, как много звезд на небе и как бесчислен песок на берегу морском» (Евр 11: 12) и известно другим языкам: рус. [много] как звезд на небе (ОгольцЕв 2001: 200); Укр. мов зірок на небі (КРАВЦОВА 1981: 9); лемк. як на небі звіздох (ВАРХОЛ-ІВЧЕНКО 1990: 89); бел. багата (многа) як зорак (зораў) на небе (Янкоўскі 1973: 12, 415). Здесь библейские представления о звездах сосуществуют с народными: «неисчислимость звезд на небе символизирует изобилие урожая, приплода скота, плодов, ягод и т. п.» (Азимов-Толстой 1995: 119).

${ }^{7}$ Рус. как горчичное зерно, с горчичное зерно (КСБФ 1997); яко зерно горчично (шутл.) (Михельсон 2: 575) - ср.: «Оно [т. е. Царствие Божие] - как зерно горчичное, которое, когда сеется в землю, есть меньше всех семян на земле; а когда посеяно, всходит и становится больше всех злаков» (Мк 4: 31-32).

${ }^{8}$ Фразеологизм с многочисленными вариантами (они не приводятся) известен многим языкам: рус. беречь (хранить, оберегать, охранять, стеречь) как зенииу ока [своего] (зрачок глаз); укр. берегти (охороняти, стерегти, пильнувати) як зіницю ока [в голові (лобі)] (СФС 1988); бел. берагчы (аберагачь) як зрэнку вока (ЛЕПЕшАў 1: 453); болг. пазя (вардя, гледам) като зеницата (зениците) на окото (на очите си); пазя (вардя, гледам) като зеницата си (КювЛИЕВА-МишАЙкОВА 1986: 176, 177); пазя като зеницата на окото си (БРФС 1974: 227); грижа се като зеницата на окото си за някого, за нещо (FINK 2006: 340); макед. чува некого, нешто (пази на некого, нешто) како зеница во око (FINK 2006: 340-341); серб. чувати (пазити) кога као зенииу ока (РCXКЈ 2: 301); чува као зеницу ока свог (очну зенииу) (PAVLICA 1960); гледати као зенииу (РСХКЈ 1: 498); слвн. с̌иvati kot punčico svojega očesa koga, kaj; paziti kot na punčico svojega očesa na koga, kaj (FINK 2006: 340-341); хорв. čuvati (paziti) koga, što kao 
167; RSFS 1998: 186); čakat' ako [na] mannu z neba 'ждать с большим нетерпением (и часто тщетно) того, что ожидают в изобилии, на что очень сильно надеются, уповают' (RSFS 1998: 263); pozerat' sa ako na mannu nebeskú '1. смотреть как на что-л. желанное, крайне необходимое; 2. о чем-л., воспринимаемом в качестве внезапно и в изобилии получаемого блага' (RSFS 1998: 505); spadnút' (prist') ako manna z neba 'получить что-л. без усилий и труда' (KSSJ 2003: 315, MATOLÁKOVÁ 2013) ${ }^{9}$ и т. д.

Обратимся к устойчивым сравнениям союзного типа с компонентом-персонажем Библии. К ним относятся: сам Творец: verit' ako Bohu ${ }^{10}$ 'верить всецело, полностью, безоговорочно, не требуя никаких доказательств' (SKLADANÁ 1993: 92); kývol rukou ako pánboh na Oravu' 'перестать обращать внимание, стать абсолютно равнодушным’ (ZÁTURECKÝ 2005: 551); служащие или противостоящие ему сверхъестественные существа: Letel ako anjel, [a] spadol ako

zjenicu oka (MATEŠIĆ 1978: 215, MENAC 1973: 95); čuvati (paziti) koga, što kao zjenicu oka [svoga] (MENAC 2001: 66, FINK 2006: 340-341); paziti na koga, na što kao na zjenicu oka (FINK 2006: 341); в.-луж. hladać (škitać, zwarnować, wobarnować) něšto kaž zerničku swojeho (samsneho) woka (wóčka) (IVČENKO-WÖLKE 2004: 380, 438); польск. strzec (pilnować) jak źrenicy oka [swego]; strzec (bronić, pilnować) jak źrenicy oka (w oku) (NKP 3: 336, SKORUPKA 1: 234, 589; KSJP 1996); miłować jak źrenice oka (SKORUPKA 1: 589); кашуб. strzec jak jabłuszko w głowie (LORENTZ 1: 283); чеш. hledět si (šetřit) jako zř́telnice v oku (ZAORÁLEK 2000: 559); střežit jako zornici (zř́telnici) [svého] oka (MOKIENKO-WURM 2002: 641, FINK 2006: 340); bdit nad kým jako nad zrítelnici [svého] oka; pečovat o koho jako o zř́telnici [svého] oka (MOKIENKO-WURM 2002: 643); англ. to keep a person as the apple of one's eye; голл. liefhebben als de appel zijner ogen (RöHRICH 1: 112); нем. jmdn. (etw.) wie seinen (eigenen) Augapfel (be)hüten (устар. wert halten) (НУФС 1: 54, WALTER 2008: 44-45) и др.

${ }^{9}$ По Библии, Бог каждое утро посылал с неба пищу иудеям во время их исхода из Египта через пустыню в землю обетованную, что и мотивировало появление фразеологизмов: рус. ждать (ожидать) как манны небесной (МиХельСОн 1: 535, ФСРЯ 1986: 237); жаждать как манны небесной (ФСРЯ 1986: 237); смотреть (глядеть) как на манну небесную (ФСРЯ 1986: 237, ССРЯ 2003: 237); сыпаться / посыпаться как манна небесная (манна с неба); как манна небесная (ССРЯ 2003: 237); укр. ждати (очікувати, чекати) як манни небесної (манну небесну; мани [манну] з неба); як манни небесної з неба чекає (УРФС 1978: 312); жадати як манни небесної (небесну; з неба) (УРФС 1978: 312); бел. чакаџь як манны нябеснай (ЛЕПЕШАў 2: 18); болг. чакам като манна небесна (БРФС 1974: 323); серб. падати као мана с неба (РСХКЈ 3: 291); хорв. čekati kao manu nebesku (s neba); gledati kao u manu nebesku (MENAC 1983: 23); pasti / padati kao mana s neba (MATEŠIĆ 1982: 331); kao da pada mana z neba (VRANIĆ 2005: 145); kod mana nebeska (BogOvić 1999: 149, 160); кашуб. to jakbë manna z nieba zleca; kapną nóm (zôróbek) jak manna z nieba 'неожиданно' (TREDER 1989: 136).

${ }^{10}$ Рус. верить/поверить кому как Богу (в кого как в Бога); верить/веровать в кого, во что как в Бога (ОГольцЕВ 2001: 62-63; ССРЯ 2003: 37, SČF 1983: 321-322); польск. wierzyć jak w Boga (Pana Boga na niebie) (NKP 3: 682).

${ }^{11}$ Орава [находится в Западных Татрах - И. К.] в прошлом была одним из наибеднейших краев Словакии (ZÁTURECKÝ 2005: 565). Эту же структурно-семантическую модель имеют лемк. махати руков як бог на Татры; махнати руками як бог над Чабинами (ВАРХОЛ-ІВчЕНКО 1990: 116). Так как в народном сознании с Творцом отождествляется Иисус, то известные лишь в Карпатском регионе сравнения имеют варианты: слвц. mávnut' rukou ako Kristus nad Slovenskom (SNK); лемк. махати руков як Христос на Kарпаты; махнути руков як Iсус на Cтропковы (ВАРХОЛ-ІВЧЕНКО 1990: 116). Они являются квалитативными вариантами с субъектом и объектом действия известного многим языкам фразеологизированного жестового образа. 
$\check{c ̌ e r t ~}^{12}$ ' 1 . большие приготовления не принесли никакого результата; 2. многообещающее начало привело к плохому, неудачному концу’ (SMIEŠKOVÁ 1974: 11); представители фауны: žit' ako vtáctvo nebeské 'жить беззаботно, беспечно, бездумно, без обременения житейскими заботами, не думая о завтрашнем дне ${ }^{\prime 3}$ (RSFS 1998: 427) и люди. Ввиду обширности материала ограничимся описанием сравнений с безымянными и наделенными именами героями.

Шутливое [je ich] ako apoštolov 'много' 14 (SмIEŠKOvÁ 1974: 12) восходит к новозаветным сказаниям, согласно которым «апостолы - ученики Иисуса Христа, проповедующие его учение, прежде всего - первые двенадцать учеников» (МЛТ 2010: 51). Поэтому о ком-либо совершенно не нужном говорят: je ako trinásty apoštol (FS 1996: 56). Професcop Йозеф Млацек отмечает, что семантика фразеологизма bolo ich ako apoštolov 'двенадцать' заменилась на значение ‘много' в результате снижения известности текста Библии в период социализма (МLACEK 2007: 209-210).

Особенность разговорной речи - ярко выраженная субъективность активизирует переход многих книжных субстантивных фразеобиблеизмов в разряд компаративных: milosrdný samaritán 'о человеке, бескорыстно, caмоотверженно, любовно оказывающему помощь больным, слабым, несчастным' $\rightarrow$ byt' ako milosrdný samaritán (FS 1996: 13); starat' sa o niekoho ako mi-

${ }^{12} \mathrm{Cp.} \mathrm{с} \mathrm{ироничными} \mathrm{пословицами:} \mathrm{рус.} \mathrm{Летел} \mathrm{-} \mathrm{как} \mathrm{ангел,} \mathrm{упал} \mathrm{-} \mathrm{как} \mathrm{черт} \mathrm{'1.} \mathrm{(калинин.)}$ о падении и ушибах после необдуманных, рискованных действиях, движениях' (ТуркинАСтроговА 1989: 24); '2. (ленингр., помор.) о человеке, начавшем что-л. делать с добрыми намерениями, но завершившим дело неудачно’ (БАХтин 1982: 448, МЕРкурьев 1997: 45); бел. Лячела як ангел, ударылася як чорт 'о безуспешном завершении удачно начавшейся работы' (Довровольский 1894: 132).

${ }^{13}$ Рус. жить как птица (птичка) небесная (божия) 'жить беззаботно, беспечно, бездумно’ (ФСРЯ 1986: 368), ‘жить вольно, без обременения житейскими заботами’ (ССРЯ 2003: 351), 'не иметь самого необходимого (прав, имущества, пищи и т. п.)' (КСБФ 1997); укр. жсти як птиия небесна; жити як птаха (пташка) небесна (як птаство небесне) (http://stalivyrazy. org.ua/everyfile2.php?transfer=folders/pe/ptixa.html); бел. жыць як птушка нябесная (http://www. classes.ru/all-byelorussian/dictionary-russian-byelorussian1-term-76725.htm); кроме того, встречается в текстах: «Стасункі з Куліком у Алеся былі асаблівыя. Ён у самым сапраўдным сэнсе гэтага слова падкормліваў нашага славутага мастака й грамадзкага дзеяча, які, ужо даўно й невылечна хворы, жыўяк птушка нябесная ў сваёй майстэрні-гарышчы і адышоў у Вечнасьць зусім хутка пасьля Каралёва» (Імёны Свабоды: Алесь Каралёў. Радыё Свабода, 19.10.2006 http://www.svaboda.mobi/a/774871.html); «Як успамінала Н. Васільева, Рома ,заўсёды жық̆, бы птушка нябесная, не ведаючы, што будзе есці і піць, ува што апранацца. Толькі адна была стыхія - мастацтва...”» (Б. Крэпак: «Я хачу жыць!..» Культура, 2010/25 - http://www.kimpress.by/ index.phtml?page=2\&id=4195\&mode=print); «Раман Мацвеевіч жыу, як птушка нябесная, піша яго жонка Надзея Міронаўна. - Ён не ведаў, што будзе есці, піць, ува што апранацца. Чаравікі яго для моцы былі перавязаныя дротам. Грошай не было, а яму патрэбны быў матэрыял...» (Карціны студэнта з Лебедзева трапілі ў Траццякоўку - http://news.21.by/other-news/ 2012/10/01/630155.html); болг. живея като птичка божия (КювлиЕВА-МишАйковА 1986: 133, ФРБЕ 1: 506); серб. као птица небеска живети (РСХКЈ 5: 281); хорв. živjeti kao ptica nebeska (MATEŠIĆ 1982: 539); польск. żić jak [te] ptaki niebieskie (SKORUPKA 2: 280).

${ }^{14} \mathrm{Cp}$. и с чеш. шутл. je (bylo) jich jako [svatejch] apoštoli̊ 'двенадцать или множество' (ZAORÁLEK 2000: 423, SČF 1983: 34); польск. byto jich jak apostołów (NKP 1: 24); кашуб. jak aposztołów tëlé ijch tam bëto 'о многодетной семье' (TREDER 1989: 129). 
losrdný Samaritán (http://slovnik.azet.sk); ako milosrdný samaritán kto ${ }^{15}$ (SNK). В составе сравнения может быть производное от имени библейского персонажа: stát' ako Lótova žena' ${ }^{16}$ 'о неожиданно застывшем, оцепеневшем от ужаса или удивления человеке' (VSRS 2: 86). Фразеологизм связан с ветхозаветной историей уничтожения Господом жителей Содома и Гоморры за их прегрешения и спасения «из среды истребления» праведника Лота и его семьи. Однако жена Лота нарушила запрет небесных посланников, оглянулась - и тут же обратилась в соляной столб: stát' ako sol’ný stĺp ${ }^{17}$ (SMIEŠKOVÁ 1974: 235).

К библейским относятся и обороты, «деривационно связанные с Ветхим и Новым Заветом или апокрифическими (неканоническими) христианскими текстами» (ІвчЕнко 1999: 190), так как семантика части выражений восходит к христианским легендам и фольклору на библейские сюжеты. Например, имплицированием апокрифического мифа на библейский мотив (Ин 21:2023 ) выводится семантика фразеологизма večný žid 'беспокойный, ищущий, вечно неудовлетворенный человек, скиталец', ставшего базой для компаративизма blúdit' (túlat's a a pod. [po svete]) ako Ahasver (večnýžid) ${ }^{18}$ 'о внутренне

${ }^{15}$ Рус. заботиться / позаботиться о ком как [добрый] самаританин (самаритянин) (SČF 1983: 311); кто как добрый самаритянин (милостивый самарянин) (НКРЯ); чеш. [být (starat se o někoho) jako] milosrdný Samaritán (SČF 1983: 311, CzPS 1996: 229); польск. [być (pielęgnować kogoś) jak] milosierny Samarytanin (CzPS 1996: 229); pomagać/pomóc komuś jak mitosierny Samarytanin; в.-луж. smilny kaž Samarita w sćenju 'милосердный как самаритянин в Евангелии' (IVČENKO-WÖLKE 2004: 306).

${ }^{16}$ Чеш. stat (züstat) jako Lotova žena (ZAORÁLEK 2000: 560, SČF 1983: 409). В русских сравнениях как Лотова жена (жена Лота) стоять (встать) (МиХЕЛЬСОН 1: 400, БЕТЕХТИНА 1999: 99, 166; КСБФ 1997); застыть как жена Лота («аки Лотова жена»), окаменеть как Лотова жена (подобно жене Лота) (НКРЯ) морфологическая вариантность связана с конкуренцией форм, выражающих притяжательно-определительные отношения. Ср. также польск. stata jak żona Lota; stojąc nieruchomie jak córa Lota (NKP 2: 316); англ. [stand there like] Lot's wife (CzPS 1996: 142); нем. dastehen wie Lot's Weib (SČF 1983: 409); фp. être planté (pique) là comme la femme de Loth (SČF 1983: 409).

17 Это устойчивое словосочетание известно многим народам. Сопоставление его в плане внешней формы обнаруживает как сходство, так и различия, касающиеся в основном количественного состава и связанного с ним грамматического оформления, а также системных отношений - наличия или отсутствия вариантов: рус. стоять как [соляной] столб (БМС 1997: 156); стоять (остановиться) неподвижно как Лотова жена, обращенная (превратившаяся) в соляной столб; стоять остолбеневшая как Лотова жена (НКРЯ); польск. obrócić się w stup soli jak żona Lota; stanat jak żona Lotowa obrócona w stup solny; stała jak stup żony Lotowej; stoi jak stup soli (NKP 2: 316); zamienić się $w$ stup soli [jak żona Lota] (KSJP 1996, ПРФС 2: 416); stać jak stup soli (ПРФС 2: 416); кашуб. stojec sztiwno jak ten bôtwón solë (TREDER 1989: 138); нем. wie eine Salzsäule sitzen (stehen) (WALTER 2008: 249); sie stand da wie zur Salzsäule erstarrt (НБФР 2: 249). В эллиптических вариантах опущение компонентов вызвано их семантической избыточностью и принципом языковой экономии, означающим «минимальную затрату речевых усилий для обеспечения максимального понимания собеседником» (МокиЕнко 1989: 99). К этому же сюжету восходят рус. оглядываться [назад] как Лотова жена (НКРЯ) и чеш. mlč́ jako Lotova žena (ZAORÁLEK 2000: 609).

${ }^{18}$ Рус. скитаться (странствовать, бродить) [по свету] как Вечный жид; чеш. bloudit jako věčnýžid (Ahasver) (SČF 1983:32, CzPS 1996: 16); польск. chodzi tu i tam (i tu, i tu) jak Wieczny Żyd (KRZYŻANOWSKI 3: 250, NKP 3: 986); ttucze się jak wieczny Żyd (ŁĘGA 1933: 219); кашуб. chodzëc po wsë kiej nen wieczni Żid; chodzëc jak Wieczny Żid [po swiece] (TREDER 1989: 155-156). 
неспокойном, неудовлетворенном, постоянно меняющем места пребывания человеке' (SмIEŠKOVÁ 1974: 10, FS 1996: 13).

Коннотации с наготой прародителей рода человеческого - наиболее активные семантические их характеристики, «поэтому по частотности употребления и количеству производных эта сема, пожалуй, - наиболее продуктивна как в славянских, так и других европейских языках» (МокиЕнко 1998: 21): byt' [nahý] ako Adam (KSSJ 2003: 33, FS 1996: 13); byt' [nahi] ako Adam a Eva (FS 1996: 13); ako Adam a Eva (FS 1996: 30); диал. holi jag Adam ${ }^{19}$ (SSN 1994: 54). Материалы Словацкого национального корпуса (SNK) позволяют вычленить компаративизмы ako Adam v raji ${ }^{20}$; začinat' ako Adam v raji 'начинать с самого начала, с нуля, 21.

Но наиболее интересны идиоэтничные сравнения. К сюжету о запретном плоде с древа познания добра и зла восходит zahtadel sa ako Eva do jablka ‘загляделся как Ева на яблоко' (ZÁTURECKÝ 2005: 550); тема изгнания первого грешника из рая обыграна в utekat' ako Adam z raja 'быстро убегать, уносить ноги' (ZÁTURECKÝ 2005: 274). Диалектный оборот narobení jag Adam 'очень уставший (от работы)' (SSN 1994: 54) можно связать со словами Творца, адресованными первому человеку при изгнании из Эдема: «В поте лица твоего будешь есть хлеб» (Бт 3: 19), т. е. возделывая ту самую землю, из которой Адам был взят, «И выслал его Господь Бог из сада Едемского, чтобы возделывать землю, из которой он взят» (Бт 3: 23).

Дериватами библейских имен в народной языковой традиции являются названия растений; на базе одного из них возник оборот је ako Adamovo rebro 22 'очень худой' (ZÁTURECKÝ 2005: 85).

Ветхозаветная история соперничества Иакова и Исава, долгожданных сыновей-близнецов Исаака и Ревекки (Бт 25-35), носит характерные черты близнечного мифа: Исав был «человеком, искусным в звероловстве, человеком полей; а Иаков человеком кротким, живущим в шатрах. Исаак любил Исава, потому что дичь его была по вкусу его; а Ревекка любила Иакова» (Бт 25: 27-28). Первым родился Исав (и поэтому он считался первородным), «красный весь, как кожа; косматый» (Бт 25: 25). Библейское описание внешности Исава (евр. 'éśaw 'волосатый'), все тело которого было покрыто рыжими волосами, отразилось в устойчивых сравнениях: слвц. је (byt') zarastený (chlpatý) ako Ezau (FS 1996: 13, 28); чеш. [být] chlupatý (zarostlý) jako Ezau (ZAORÁleK 2000: 590, 442); je (vypadá) jako Ezau 'волосатый, лохматый; зарос-

${ }^{19}$ О тождествах в других языках см. КузНЕцОВА 2012: 128-132.

20 „Scéna bola síce pripravená vel’mi citlivo, aby pred divákmi nepobehoval úplne ako Adam $v$ raji, no z kontroverznej inscenácie Tvár v ohni odchádzali niektorí diváci spohoršením“; „ty len nazývaš menami to, čo je, ako Adam v raji“ (SNK). 1999).

${ }^{21}$ „Krepuch začínal ako Adam v raji. Takmer od nuly“ (A. Brázda: Nedokončené pokolenie,

22 Длинные острые листья растения горичник похожи на реберную кость; название известно и восточным славянам: рус. адамово ребро (РодионовА 2004: 127); укр. адамове ребро (СУM 1:24). 
ший щетиной),23 (MOKIENKO-WURM 2002: 137); zrzavý jako Ezau 'рыжий, рыжеволосый’ (ZAORÁLEK 2000: 700). Этот персонаж известен тем, что продал за чечевичную похлебку право первородства своему брату Иакову. Этот сюжет нашел отклик в литературе: слвц. «Nech nik nie je smilník alebo l’ahkomysel'ný ako Ezau, ktorý za trochu jedla predal svoje práva prvorodeného» (SNK); pyc. «А что до нее, до самой Данки, то она готова отдать за его любовь все, и свободу свою и все грядущее счастье, так же легкомысленно, как голодный Исав продал право своего старшинства за чечевичную похлебку Ревекки» (Н. С. Лесков: Божедомы, 1868); «Как Исав... как Исав, за чечевичную похлебку!» (В. В. Крестовский: Панургово стадо, 1869); «Вы фарисеи и лицемеры! Вы, как Исав, готовы за гориок чечевицы продать все, так называемые, основы ваши! Вы указываете на брак, как на основу вашего гнилого общества, а сами прелюбодействуете! вы распинаетесь за собственность, а сами крадете!» (М. Е. Салтыков-Щедрин: Благонамеренные речи. Переписка, 1876); «Меня с вами начали смешивать... Такой же кулак, говорят, как и все они, воротила, выжига. А я магистерский диплом имею... За чечевичную похлебку, как Исав, продал свое первородство. Стал с вашим братом якшаться» (П. Д. Боборыкин: Китай-город, 1882).

Библейский сюжет борьбы Иакова с Богом, называемым в Библии «Некто», обыгран в строках: слвц. «chcú sa s Bohom súdit' ako Jób, zápasia s ním ako Jakob, kričia $k$ nemu ako David, no nikdy od nego cel'kom neodchádzaj» (SNK); рус. «...И, как с Иаковом, неведомая сила / Со мной боролась в тьме ночей» (Н. А. Некрасов: Труженик, 1837-1843); «Тургенев уверял, что он, как Иаков, боролся с Иеговой во сне...» (П. П. Гнедич: Книга жизни, 1918); «Благослови... всех, кто, как Иаков, в потемках борется с Богом...» (митрополит Антоний [Блум]: Вместо послесловия, 1980); «Что делать и кто виноват? Виноват я - струсил и бежал из России в поисках лучшей жизни. Что делать?! Бороться, как Иаков» (М. Казаков: Актерская книга, 1978-1995); «Я рассвирепел настолько, что готов был, как Иаков, бороться с кем угодно и где угодно» (В. Скрипкин: Тинга, 2002); «Математика... наука, в которой человек соревнуется, почти как Иаков, с Богом, открывая Вечные Истины...» (Б. Кушнер: Учитель, 2003).

Ветхозаветный герой Самсон прославился своей необыкновенной силой, что отражено в сравнениях: слвц. mocný ako Samson (MATOLÁKOVÁ 2013); рус. сильный как Самсон (БМС 1997: 272); сила как у Самсона (ССРЯ 2003: 377); чеш. silný jak samson (ZAORÁleK 2000: 523); je silný jako Samson; má sílu jako Samson (MoKIENKо-WURM 2002: 460); в.-луж. sylny kaž Simson (RADYSERB-

${ }^{23}$ Внешний облик Исава нашел отражение и в русской литературе XIX века: «В тот самый день, как пришел к нему капитан, он... заснул на своем худеньком диванишке, облаченный в узенький ситцевый халат, из-под которого выставлялись его громадные выростковые сапоги и виднелась волосатая грудь, покрытая, как у Исава, густым волосом...» (А. Ф. Писемский: Тысяча душ, 1858); «И вот он одичал... Весь он, с головы до ног, оброс волосами, словно древний Исав, а ногти у него сделались, как железные» (М. Салтыков-Щедрин: Дикий помещик, 1869). 
WJELA 1902: 259); польск. silny (mocny) jak Samson (NKP 3: 142); нем. stark wie Simson (WALTER 2008: 270). Библейский силач убил ослиной челюстью тысячу филистимлян, откуда польск. wywija jak Samson ośla szczęka 'размахивает как Самсон ослиной челюстью' - о рассвирепевшем человеке (KRAJEWSKI 1993: 390). Сильнейшим из сильных он стал благодаря своим волосам, которые согласно данному его родителями ангелу обету не должен был стричь. Этот мотив часто используют авторы произведений. ${ }^{24}$ Героическая гибель библейского силача дала жизнь рус. погибнуть как Самсон 'пожертвовать своей жизнью, уничтожив многих врагов’; фразеологизм встречается в текстах: «Быть может, Бэйли вобрал в себя все отчаяние капиталистов, обреченных историей, и, как Самсон, решил погибнуть вместе со своими врагами?» (А. Р. Беляев: Продавец воздуха, 1929); «Он погиб, как наш герой Самсон, унеся с собой многие жизни врагов-филистимлян... (А. Бовин: Пять лет среди евреев и мидовцев, или Израиль из окна российского посольства, 1999).

Диалектные польские компаративизмы żyje jak Samson 'живет уединенно, нелюдимо, в полном одиночестве, не желая общаться'; chodzi jak Samsón 'ходит в одиночестве' (NKP 2: 142); кашуб. sedzec jak taki samsón 'нелюдим' - о молчуне (TREDER 1989: 137) развивают другой сюжет повествования о Самсоне: расставшись с женой, он жил один в пещере Етам (Суд 15: 1-8). Вторичная ассоциация онома Самсон проявляется и в чеш. hledí jako samson 'глядит угрюмо, с досадой' (ZAORÁLEK 2000: 523).

На сходстве положения основано сравнение sú ako Dávid a Goliáš (SKLADANÁ 1999: 50), имеющее эквиваленты в других языках: чеш. jsou jako David a Goliáš (SČF 1983: 78); рус. как Давид и Голиаф (ССРЯ 2003: 93); как Давид с Голиафом (RUIZ-Zorilla CRUZATE 1996: 126); польск. wyglada jak Dawid przy Goliacie (NKP 1: 696); [sajak] Dawid i Goliat (CzPS 1996: 52); кашуб. wëzdrzec jak Dawid i Goliôt (TREDER 1989: 137); англ. [they are like] David and Goliath (CzPS 1996: 52); wie David und Goliath aussehen (SČF 1983: 78) - '1. о резко отличающихся друг от друга, неравноценных по качествам и внешнему виду соперниках: один очень малого роста и слабый (но умный, ловкий и хитрый), другой - чудовищно большой и сильный (но неповоротливый, тяжеловесный, медлительный и туго соображающий); 2. 'о людях низкого и высокого роста; 3. 'о людях хрупкого и мощного телосложения'. Однако в текстах фразеобиблеизм может быть приложим к необычному для него объекту, менять

${ }^{24}$ Слвц. «Pre väčšinu neapolských chlapcov je 20-ročný stredopoliar z Banskej Bystrice hrdinom. Mnohí majú doma jeho dres, viacerí sa nechali ostrihat’ ako on. „Je ako Samson, jeho sila je vo vlasoch“, hovoria chlapci. Povedal to vraj Hamšíkov dvorný kaderník Rino Riccio. „Vždy, ked’ ho ostrihá, strelí Hamšík gól“", smejú sa mladí fanúšikovia Neapola, ktorí vysvetl'ujú, ako sa dostanem do Castel Volturna» (SME Vol'by, 21.04.2008 - SNK); «Musíš sa dat' ešte ostrihat', vyzeráš ako Samson» (G. Calinescu: Záhadná Otília, 1984 - SNK); рус. «Не блистая иными красами, / Как Самсон, я силен волосами» (Н. П. Карабчевский: Что глаза мои видели. Т. 1. В детстве, 1921); «Она подумала - если струсить, и дать себя в руки эскулапам, и позволить проделать с собою все, что проделывают в таких случаях, выигрывая несколько месяцев у смерти, то она, конечно, потеряет свои прекрасные волосы, как Самсон, и так же останется беззашитной» (Д. Рубина: Высокая вода венецианцев, 1999). 
предметную отнесенность (БЕТЕХТинА 1999: 127): «Malý opel a obrovský mercedes vyzerali ako Dávid a Goliáš» (MY Zvolensko-podpolianske noviny, 21.08. 2007 - SNK); «Это истина «откровения» - и она стоит, малая и незаметная, не видимая даже и oculis mentis (духовным зрением), безоружная и беззащитная пред неисчислимым воинством аргументов всей исторической философии, как библейский Давид стоял пред огромным, вооруженным с головы до ног Голиафом. И нет у нее даже пращи, которую имел в своем распоряжении молодой пастух, будущий великий царь и псалмопевец. И все же, ничем не защищенная и безоружная, она вступила в борьбу с ,мудростью века“» (Л. И. Шестов: Афины и Иерусалим, 1938). На основе библейского рассказа о единоборстве юноши-пастуха Давида и филистимского великана из города Геф возникли кашуб. jic jak Dawid na Goliata 'идти как Давид на Голиафа' - о слабом на вид человеке невысокого роста, выступающем против более сильного противника (TREDER 1989: 137) и рус. биться как Давид с Голиафом: «И пускай бы, как Давид с Голиафом, бились: чей верх, того власть» (М. А. Шолохов: Тихий Дон, 1928-1940). Впоследствии, став правителем Израиля, Давид решил сделать религиозным центром своего царства Иерусалим, для чего туда нужно было перевезти ковчег завета. Во время обеих попыток (неудавшейся и увенчавшейся успехом) совершить это народ во время шествия, возглавляемого царем, веселился и плясал. Этот факт стал фразеологически значимым для поляков: tańcuje jak król Dawid przed Arka (KOMORNICKA 1994: 93); в русском языке оборот встречается в текстах: «Так это у меня и осталось: первый Белый, танцующий перед Гете и Штейнером, как некогда Давид перед ковчегом. В жизни символиста все - символ. Не-символов - нет» (М. Цветаева: Пленный дух - моя встреча с Андреем Белым, 1916); «Помню МусинПушкин, бывший тогда попечителем Казанского университета, звавший нас к себе танцевать, насмешливо уговаривал отказавшегося брата (Дмитрия) тем, что и Давид плясал перед ковчегом» (Л. Толстой: Исповедь, 1881).

Имя божьего страстотерпца Иова в устойчивых сравнениях католиков и протестантов стало символом долготерпения: trpezlivý (trpiet') ako Jób ${ }^{25}$ (SKLADANÁ 1999: 170): именно оно помогло праведнику преодолеть все испытания и телесные муки и вновь приобрести милость Господа. У некоторых народов имя Иова ассоциируется с бедностью. ${ }^{26}$ Библейский страдалец стал также синонимом всяческих несчастий, что обыгрывают писатели, ср. тексты:

${ }^{25}$ Чеш. trpělivý (trpi) jako Job (ZAORÁLEK 2000: 459); snášet (nést) něco [trpélivē] jako Job (SČF 1986: 142); кашуб. cerplëwi jak Job (TREDER 1989: 136); в.-луж. sćerpny kaž sputowany ['испытуемый'] Hiob (RADYSERB-WJELA 1902: 254); хорв. strpljiv kao (ko) Job (RAGUŽ 1979: 21, MENAC-MiHALIĆ 2003-2004: 366); англ. [as] patient as Job (БЕТЕХТИНА 1995: 28); фp. être patient comme Job (SČF 1986: 142); венг. türelmes, mint Jób (информант - Й. А. Балажи).

${ }^{26}$ Рус. бедный (нищий) как Иов (МиХЕЛЬСОН 1: 86, ОГОЛЬЦЕВ 2001: 225); укр. бідний як Іов (НУФС 1: 341); бел. бедны як Іоў (МАСлОВА 2001: 168); болг. беден като Йов (КювлИЕВАМишАйковА 1986: 100); сиромах като праведния Йов (НБФР 1: 107); польск. nędzny jak Hiob (KOMORNICKA 1994: 143); англ. [as] poor as Job (БЕТЕХTИНА 1995: 28); нем. arm wie Hiob (Job) (HУФС 1: 341, WALTER 2008: 141); фp. pauvre comme Job (WALTER 2008: 142) - 'о полностью обнищавшем, впавшем в крайнюю бедность человеке'. 
«- Íha, to ste teda boháč! - prerušila som ho. - Ako Midas, ale neštastnejšś ako Jób, - povedal dvojzmyselne a vystrúhal takú grimasu, akoby si bol ústa o jedlo popálil» (LÁszLovÁ 2004); «Он, несчастный, как Иов, заснул с улыбкой на губах, вера замерла в его потухающих глазах, закрытых таким же фанатиком, как он, - Маццини» (А. И. Герцен: Былое и думы. Ч. 6. Англия, 1864).

Несмотря на все ниспосланные испытания, Иов остался благочестив: «Наг я вышел из чрева матери моей, наг и возвращусь. Господь дал, Господь и взял; да будет имя Господне благословенно!» (Иов 1: 20-21). Это помогло ему вновь приобрести милость Господа: в награду за безграничную веру в непостижимую мудрость божественного провидения Бог вновь одарил Иова сыновьями и дочерьми, вернул все его имущество и здоровье (Иов 42: 10-17).

Справедливость божьего приговора мы видим и в библейском сказании о ветхозаветном пророке, беззаветно преданном Яхве. Свято соблюдающий религиозные обряды, Даниил не мог подчиниться приказу царя Дария, противоречащему заветам Моисея (не молиться тридцать дней), и продолжал молиться своему Богу трижды в день, о чем его враги донесли царю, и тот с тяжелым сердцем приказал бросить прорицателя в ров с голодными львами. Однако Даниил остался цел и невредим благодаря божественному вмешательству. Эта история дала жизнь обороту byt' ako Daniel v jame levovej 'быть в очень опасной, безвыходной ситуации, в окружении врагов'; citit' sa (pripadat' si) ako Daniel v jame levovej ${ }^{27}$ 'об ощущении безысходности, беззащитности в опасном месте, угрожающей ситуации' (SKLADANÁ 1999: 170).

Другое назидательное сказание связано с ветхозаветным пророком Ионой, который по приказу Яхве был проглочен китом и просидел в его животе трое суток, неустанно благодаря Бога за то, что Господь не дал ему утонуть. Эта библейская история запечатлена в компаративизмах: слвц. citit' sa ako Jonáś v bruchu vel’ryby (MAтOLÁKOVÁ 2013); польск. (диал.) krynci sie jak Jónasz we wielorybie (NKP 1: 874); кашуб. sedzec [w pryzë] jakno Jónasz w wielorëbie (TREDER 1989: 137).

Лазарь Убогий, персонаж евангельской притчи о богаче и нищем, стал символом крайне тяжелого физического состояния: например, byt' (ležat') ako lazár (VSRS 2: 44); chorý ako Lazár 'лежать пластом (о тяжело больном, инвалиде)' (MATOLÁKOVÁ 2013). ${ }^{28}$ Материалы SNK позволяют вычленить сравне-

${ }^{27}$ Чеш. [být (citit se, pripadat si) jako] Daniel v jámě lvové (SČF 1983: 77); польск. [czuć się jak] Daniel w jaskini lwów (lwiej jamie); англ. (be like) Daniel in the lions' den (CzPS 1996: 52); нем. wie Daniel in der Löwengrube (der Höhle des Löwen) sein; фp. être comme Daniel dans la fosse aux lions (SČF 1983: 77). В русском языке данным фразеологизмам соответствует оборот без именного компонента: [чувствовать себя где] как в логове льва (ССРЯ 2003: 222).

${ }^{28}$ Рус. лежать как Лазарь (вроде Лазаря); бел. ляжаць як Лазар 'о лежачем больном, инвалиде', выглядаць як чысты Лазар 'о болезненном, изможденном человеке' (FEDEROWSKI 1935: 170); як Лазор мучыция ‘о тяжелобольном, обычно лежачем калеке' (СБГ 3: 90); польск. leżeć jak łazarz (CzPS 1996: 137); leżé jak Łazarz, wyglądać jak Łazarz (łazarz) 'о бедно, грязно, по-нищенски одетом и изможденно выглядящем человеке’ (NKP 3: 338); jak Lazarz (tazarz) 'изможденный, болезненного вида, живые мощи' (ПРФС 1: 622); чеш. být (ležet) jak (jako) lazar (ZAORÁLEK 2000: 477, SČF 1983: 186); хорв. ležati [bespomoćno] kao Lazar (RIBAROVA 2001: 72) - 
ния cítit' sa ako lazár 'очень плохо себя чувствовать' (LÁSZLOVÁ 2004) и tvárit' sa ako lazar 'притворяться' 29 (LÁSZlovÁ 1997). После смерти Лазарь «отнесен был Ангелами на лоно Авраамово» (Лк 16: 22-25). Имя этого ветхозаветного патриарха ассоциируется у словаков с преклонным возрастом: byt'starý ako Abrahám $^{30}$ (FS 1996: 121); pamätat' Abraháma 'помнить Авраама'.

Если Авраам жил 175 лет, то другой библейский долгожитель - 969, с его именем связаны сравнения starý ako Matuzalem 'очень старый (обычно о человеке)' (SмIEŠKOVÁ 1974: 133); žit' [dlho] ako Metuzalem 'очень долго, 31 (VSRS 2: 152, RSFS 1998: 107). Видимо, именно продолжительностью жизни персонажа мотивированы чеш. zkušený jako Metusalém 'очень опытный' (СТЕПАНОВА 1985: 50) и рус. дряхл (дряхлый) как Мафусаил 'слабый, немощный от старости': «Евсей Лазаревич, крохотный и горбатенький, был дряхл, как Мафусаил, но излучал спокойствие и уверенность в себе, присущее скорее сильному молодому мужчине» (О. Алеман: Гороскоп. Гл. 5. Сирены и титаны, 2010). Этот фразеологизм встречается чаще в переводных текстах (Тесс Герритсен: Свидетель, 2013; Густав Майринк: Голем, 2014).

Поистине интернациональны компаративизмы с именем библейского мудреца, отражающие его непревзойденный ум: múdry ako Šalamún; hovorit' ako Šalamún 'мудро говорить' (KSSJ 2003: 733); rozhodnút' múdro ako Šalamún 'мудро рассудить'; rozum mat' ako Šalamún (SNK). Но притяжательное прилагательное от имени царя израильтян часто употребляют для создания иронии при характеристике неумного человека: múdry ako Šalomúnove plundre; múdry

\footnotetext{
‘лежать неподвижно беспомощно; быть больным’. Польск. leżeć jak Lazarz имеет еще семантику ‘лежать в одиночестве, всеми покинутым’ (ПРФС 1: 622); кашуб. leżec jak taki łazôrz 'о ком-л. грязном, лежащем в грязи или в лохмотьях' (TREDER 1989: 137). Хорв. ležati kao Lazar совмещает в себе значения ‘быть немощным’ и ‘быть очень бедным’ (MATEŠIć 1982: 304). Апеллятив от имени означает: слвц. lazar 'увечный, больной, калека, бедняк'; серб. лазар 'калека, бедняк, нищий, попрошайка'; польск. tazarz 'бедняк, бедняга, горемыка'; кашуб. tazôrz 'нищий'; чеш. lazar 'больной, калека; доходяга, дохлятина'.

29 Эта семантика в русском языке передается творительным сравнения: прикидываться / прикинуться (притворяться/притвориться) Лазарем 'притворяться больным, бедным и несчастным, стараться разжалобить кого-л.; прибедняться’. Чеш. ležet jak (jako) Lazar (lazar) получило омонимичное значение 'лежебока, лентяй'.

${ }^{30}$ Cp. чеш. být starý jako Abraham (SČF 1983: 31).

${ }^{31}$ Адъективные и глагольные обороты интернациональны: рус. стар (старый) как Maфусаил (ССРЯ 2003: 240, SС̆F 1983: 205); жить [долго] как Мафусаил (НКРЯ); укр. старий як Мафусаїл (НУФС 1: 27); болг. стар като Матусал (НБФР 1: 56, НБФР 2: 37); макед. стар као Метузалем (FINK 2006: 239); серб. стар као Метузалем; хорв. [biti] star kao (ko) Metuzalem (RAGuŽ 1979: 22, MenaC-Minalić 2003-2004: 371); слвн. star kot Metúzalem (HFR 2003: 167); в.-луж. stary kaž Metusala (IvČENKO-WÖLKE 2004: 188); чеш. [být] starý jako Methusalem (Metuzalém) (ZAORÁLEK 2000: 485, SČF 1983: 31, 204]; польск. żyt tak dtugo jak Matuzalem (NKP 2: 417); кашуб. stôri jak Matuzalem; stôri (żëc) jak Matuzalem, co żyt prawie tësac lat (TREDER 1989: 137); англ. [as] old as Methuselah (SČF 1983: 31); нем. [so] alt wie Methusalem [sein] (WW 1982: 57); голл. zo oud as Methusalem (WALTER 2008: 204); фp. vieux comme Mathusalem (SČF 1983: 31); венг. vén, mint Matuzsálem (O. NAGY 1976: 469). Заметим, что в кайкавском диалекте хорватского языка оборот ziveti kak Metuzalem имеет также значение 'жить одиноко' (MENACMiHALIĆ 2011: 480).
} 
ako Šalomúnovo pudlo (ZÁTURECKÝ 2005: 329); ${ }^{32}$ múdry ako Šalomúnove nohavice (SMIEŠKOvÁ 1974: 244); múdry je ako Šalamúnove gate (MY Oravské noviny, 13.09.2010 - SNK). ${ }^{33}$

Кроме сердца мудрого, Господь обещал даровать Соломону долголетие и сделать его самым богатым и знаменитым из всех царей в мире (III Цар 3: 11-14). И действительно «царь Соломон превосходил всех царей земли богатством» (III Цар 10: 23), однако этот мотив отражен лишь в в.-луж. bohaty kaž Salomon (RADYSERB-WJELA 1905: 13). Слух о его несметных богатствах распространился по свету. Дошел он и до славившейся своей красотой и мудростью правительницы аравийского царства Саба ${ }^{34}$, приехавшей в Иерусалим, чтобы убедиться в правдивости молвы о богатстве Соломона и «испытать его загадками». Словацкие сравнения связаны в основном с величественнонадменной походкой царицы Савской и ее манерой держать себя: chodit' ako královná zo Sáby (SS 2006 - SNK); niest'sa (príst', vplávat') ako král'ovná zo Sáby; sediet' ako královná zo Sáby; správat' sa ['держать себя, вести себя’] ako královná zo Sáby ${ }^{35}$; je ako královná zo Sáby ${ }^{36}$ (SNK). Обороты являются эксплицированными вариантами фразеологизмов без ономастического компонента: ide ako král'ovná (KSSJ 2003: 273); рус. идти (ходить, выступать) как королева (ССРЯ 2003: 188); [вести себя] как ияарииа (ССРЯ 2003: 471); чеш. jít (chodit) jako královna; нем. sie läuft [stolz] wie eine Königen (SČF 1983: 173). В них смысловая нагрузка перенесена на неономастический компонент, обеспечивая таким образом факультативность библейского имени, что не означает его выпадения из состава фразеологизма, но приводит к изменению его

32 Рус. мудрый (умный, премудрый) как [иарь] Соломон (БМС 1997: 321, ОгольцЕВ 2001: 632, НКРЯ); судить (рассуждать/pacсудить, поступать) как [иарь] Соломон (ОгольцЕВ 2001: 632, НКРЯ); укр. премудрий як Саламон; мудрий як Соломон (Саламон, Салимон); розсудив як иар Соломон (Тимошик 2007: 107); лемк. мудрый як Соломон (Шаламун, Саламун краль) (ВАРХОЛ-ІВчЕНКО 1990: 126, 118, 145); болг. мъдър като Соломон (КюВЛИЕВА-МИШАЙKOBA 1986: 162); чеш. je chytrý (moudrý) jako Šalomoun (Šalamoun) (ZAORÁLEK 2000: 535, SČF 1983: 345); польск. mądry jak Salomon (SкоRUPKA 1: 430); кашуб. madri jak [król] Salamon (TREDER 1989: 137); англ. be as wise as Salomon (Кунин 1984: 1030); голл. zo wijs als Salomo; нем. weise wie Salomo (Salomonis) (DRW 2009: 129); фp. être sage comme Salomon (SČF 1983: 345); венг. bölcs, mint Salamon [király] (VöÖ 1999: 46). Адъективное сравнение может употребляться в речи с сарказмом, но лишь в некоторых словарях при нем дана помета иутл. и ирон.: ср. слвц. (žart. i iron.) múdry ako Šalamún (SмIEŠKOvÁ 1974: 244).

${ }^{33}$ Подробнее об эквивалентах и аналогах этих фразеологизмов, а также о других компаративизмах с именем этого героя в разных языках см. КузнЕцОВА 2014: 346-347.

${ }^{34}$ Cp. чеш. být jako královna [ze Sáby] 'быть красивой и мудрой’ (SČF 1983: 173, СТЕПАHOBA 1985: 152).

${ }^{35}$ Чеш. jit (chodit) jako královna ze Sáby 'идти гордо, с преувеличенным достоинством' (ZAORÁLEK 2000: 471, SČF 1983: 173); pyšná jako královna ze Sáby 'надменна, высокомерна, горделива' (ZAORÁLEK 2000: 655); staví se ['строит из себя'] jako královna ze Sáby; nese se jako královna ze Sáby (СТЕПАНОВА 1985: 152), причем «определение ze Sáby употребляется в современном чешском языке только в качестве интенсификатора иронической оценки» (СТЕПАНОВА 1985: 153).

${ }^{36}$ Cр. контекст: «Dívam sa na ňu. Je ako král’ovná zo Sáby. Sebavedomá, ale ['самоуверенна, но’] slušná, inteligentná (L. Ťažký: Očami pútnika, 1997). 
функции: библейское имя трансформирует функцию сообщения экстралингвистической информации в экспрессивную; постпозиция ономастического компонента по отношению к определяемому слову подчеркивает его интенсифицирующее значение и придает устойчивому сравнению ироническую окраску (СТЕПАНОВА 1985: 13-14).

Центральная фигура сказаний Нового Завета - Иисус Христос. Пророк из Галилеи в народных сравнениях предстает с бородой, обросшим (может, под влиянием живописи и иконографии): слвц. vyzerat' ako Ježiš Kristus na farbotlačových obrázkoch (InZine. Magazín zameraný na financie, 13.04.2000 SNK); рус. заростий как Иисус (Кузнецова 2000: 143); оброс как Христос в пустыне; обросший бородкой как Христос 'о длинноволосом или обросшем волосами человеке' (КузнецовА 2015: 65); укр. борідка як в Iсуса, а очі як у біса (ДоьрольожА 2003: 65); бел. барада не раўнуючы як у Пана Езуса на абразе ['на иконе'] 'об аккуратно подстриженной бороде' (VARŁYHA 1970: 80); як Iсус Хрыстос распяты 'о нестриженом парне (насмешл.)' (СБНП 2011: 233); чеш. [bradatý] jako Kristus; нем. bärtig wie ein Jezus sein (SČF 1983: 175).

Со сказаниями евангелистов о снятии Спасителя с распятия связаны компаративизмы: слвц. vyzerat' ako by ho z križa sňali (GiANITSOvÁ 2000 - SNK); рус. словно с креста сняли кого (ППРН 1996: 173); как (точно) с креста снятый (ПРФС 1: 583); укр. як (мов) з хреста знятий (Юрченко-ІвчЕнко 1993: 157); лемк. як бы з креста (крыжа) зняли кого (ВАРХОЛ-Івченко 1990: 73); бел. як з крыжа (храста) зняты (FEDEROWSKI 1935: 374, ЮрчАнкA 1977: 213); польск. jak [by] z krzyża zdjęty ${ }^{37}$ (ПРФС 1: 583); кашуб. vëzdř̈̈ jak z křiža zjąti (ЕрмолА 2011: 57) - 'о бледном, худом, изможденном, болезненно выглядящем человеке'; бел. белы як з крыља зняты 'о побелевшем человеке, похожем на покойника' (СБНП 2011: 224). Их семантика в немалой степени навеяна и произведениями живописи и иконографии с сюжетом снятия тела Иисуса с креста, на которых Христос изображен истощенным и измученным.

В словарях зафиксированы следующие сравнения с именем главного героя Библии или его синонимами: osopili sa nań ['обрушились на него'] ako židia na Krista Pana; čaka ako Żidia Mesiàša (ZÁtURECKÝ 2005: 190); čakat' ako Mesiáśa (na Mesiáša) (FINK 2006: 238) - обороты мотивированы предсказаниями евангелистов о втором (новом) пришествии Иисуса Христа на землю перед концом света. Эти компаративизмы можно дополнить извлечениями из материалов Словацкого национального корпуса (SNK): sedet' v strede ['сидеть в центре'] ako Kristus (Ježiš); pokúšat' ako Ježišo na púšti 'искушать как Иисуса в пустыне'; trpiet' ako Kristus (Ježišo) [na križi]; ruky má rozhodené ako Kristus na križi; očakávat' ako Mesiáša; zjavit' sa ako Mesiáśs; $;{ }^{38}$ hl'adiet' [nan̆ ho] ['смотреть на него'] ako na Mesiáśa.

${ }^{37}$ В польском языке фразеологизм имеет также значение 'как в воду опущенный, подавленный, с несчастным видом' (ПРФС 1: 583).

${ }^{38}$ Ср. с рус. [кто, что] как явление Христа народу; явиться как Христос народу (КузНЕцОВА 2015: 72); укр. явився як Христос народові (ДоБРОЛьОЖА 2003: 151) - 'о неожиданном появлении кого-л., чего-л.' . 
Фразеологизмы с именами библейских персонажей являются «символами в квадрате»: «помимо присущего им общего символического значения, включают в свой состав имена собственные, сами по себе являющиеся символами» (DRW 2009: 19). Так, имя Иуды Искариота у многих народов употребляется в значении 'предатель'. Сюжет о предательстве им своего Учителя отразился в фразеологии: zradit' niekogo ako Judáš [Krista] 'изменнически выдать кого-л., вероломно отдать во власть, распоряжение кого-л.' (SKLADANÁ 1999: 82); zradit' niekogo ako Judáš za 40 dinárov 'предать, изменить из корыстных побуждений' (SNK). ${ }^{39}$ В результате дальнейшего развития фразеологического образа у имени появляется коннотация 'неискренний, лицемерный, плохой человек вообще': слвц. byt' falošný ako Judáš (SKLADANÁ 1999: 82); чеш. falešný jako Jidáš (ZAORÁLEK 2000: 458); в.-луж. falšny kaž Judaš (RADYSERB-WJELA 1902: 241); falšny kaž Judašowy wokoš ['Иудин поцелуй'] ${ }^{40}$ (IvČENKO-WöLKE 2004: 404); польск. fatszywy jak Judasz (SKORUPKA 1: 312); нем. falsch wie Judasch sein (SČF 1983: 141).

Злость, вероломство, коварство, подлость, продажность, жадность - вот те качества, которыми наделяется Иуда: слвц. zlý ako Judáš (MATOLÁкOvÁ 2013); чеш. kouká ['смотрит'] jako Jidáš 'не относиться искренне, дружески; быть лицемерным, вероломным’ (ZAORÁLEK 2000: 458); кашуб. kochac jak Judasz Christusa 'абсолютно не любить, лицемерить' (NKP 1: 878); венг. árulkodik ['доносит'], mint Júdás; ${ }^{41}$ tartja, mint Júdás az erszényt ['подставляет как Иуда кошелек'] (O. NAGY 1976: 320); рус. продажный как Иуда; диал. жадный как Иуда; труситься как Иуда с кошельком 'о скаредном скупом человеке' (Мокиенко-НикитинА 2008: 237); укр. вірний як Іуда в середу (ДоБРОльОжА 2003: 25); юдит на мене як той Юда Скаріотський (Скаріоџький) 'о клеветнике' (зафиксировал И. Франко, цит. по ГРом 2004: 83, САВКА 2002: 143); лемк. як Юда Шкарігодскый 'підлый, підступный' (ВАРХОЛ-ІвчЕнкО 1990: 148); бел. здрадны (здрадлівы, прадажны) як Юда (Янкоўскі 1973: 73, 129); адвярнуцица як Юда ад святой вячэры 'о человеке, который от чего-л. отказался или нечто предал’ (СБНП 2011: 477).

Из евангелистов лишь Матфей пишет о том, что Иуда, раскаявшись в содеянном, покончил с собой: «Иуда, предавший Его, увидев, что Он осужден, и раскаявшись, возвратил тридцать сребренников первосвященникам и старейшинам, говоря: согрешил я, предав кровь невинную... И бросив сребренники в храме, он вышел, пошел и удавился» (Мф 27: 3-5). Этот сюжет Книги книг и апокрифические предания о том, что Иуда повесился на осине, нашли отражение в выражениях с семантикой 'умереть позорной смертью': рус. удавиться как Иуда; уничтожить как Иуду (НКРЯ) - ср. с проклятиями: Пусть он удавится на горькой осине как Иуда Искариот! (ППРН 1996: 439);

${ }^{39}$ Об инославянских эквивалентах см. КузнЕцовА 2015: 71.

${ }^{40}$ Сравнение, как и в.-луж. košić kaž Judaš (САВКА 2002: 144); польск. catuje jak Judasz Christusa (NKP 1: 878); кашуб. całowac jak Judôsz (TREDER 1989: 130), отражает способ предательства Иудой Христа в Гефсиманском саду на горе Елеонской.

${ }^{41}$ Информант - Й. А. Балажи. 
диал. Трястись кому как Иуде на осине! (МокиЕнко-НикитинА 2008: 237); кашуб. powiesëc se jak Judôsz (TREDER 1989: 130). Мотив неминуемого наказания за измену, также связанный с повешением, содержится и в верхнелужицкой пословице Kóždy přeradnik ['предатель'] zwinuje runje kaž Judaš za šiju štryk (САВКА 2002: 144). В литовском языке есть выражение drebèti kaip epusè, Judosiui pasikorus 'трястись как осина после того, как Иуда повесился' (ВороБьЕВА 2009: 247). Видимо, именно эта библейская история косвенно отразилась и в кашуб. łazëc jak Judôsz 'избегать кого-л. из-за угрызений совести’ (TREDER 1989: 130); чеш. [nedobře] je mu jako Jidášovi ‘оказаться в неприятной ситуации’ (ZAORÁLEK 2000: 458); в.-луж. zadwělować kaž přeradnik ['предатель'] Judaš 'полностью отчаяться'; zadwělowany kaž Judaš 'полностью отчаявшийся' (RADYSERB-WJELA 1905: 22); венг. fél, mint Júdás a purgatóriumtól ‘боится как Иуда чистилища' (O. NAGY 1976: 320). Непосредственно с христианской символикой этого библейского персонажа связан апеллятив judáś (KSSJ 2003: 235).

Фразеологически значимым стало и другое предательство - троекратное отречение апостола Петра от Иисуса: zapriet' niekoho ako Peter Krista [zo stra$c h u]^{42}(\mathrm{SNK})$ - 'об отречении от старого друга, предательском отказе от признания дружеских отношений с кем-л. из корыстных побуждений, страха или трусости; совершить подлый поступок по отношению к ближнему’. Этот неблаговидный поступок Симона, Иисусом нареченного Петром [т. е. 'камень'] (Мф 16: 18), дал жизнь укр. сміливий як святий Петро 'очень трусливый' (Номис 1993: 593).

Римский прокуратор Иудеи Понтий Пилат вошел во фразеологию в связи с евангельскими повествованиями о допросе и суде над Иисусом. Матфей ввел в рассказ о судебном процессе над Иисусом эпизод, отсутствующий у других евангелистов, - знаменитую сцену умывания рук: «Пилат, видя, что ничто не помогает, но смятение увеличивается, взял воды и умыл руки перед народом, и сказал: невиновен я в крови Праведника Сего; смотрите вы» (Мф 27: 24). Символический жест омовения рук после вынесения смертного приговора, ${ }^{44}$ подчеркивающий убежденность Понтия Пилата в отсутствии вины Иисуса, о чем он прямо заявил иудеям, лег в основу фразеологизмов с семантикой '1. слагать с себя ответственность за что-л., отстраняться от исполнения чего-л., не принимать вины на себя; 2. отказываться от своей активности, инициативы, подчинившись воле обстоятельств или приказу вышестоящего': слвц. umývat' si/umyt' si ruky [ako Pilát] (SMIEŠKOvÁ 1974: 257, SKladanÁ 1993: 133); umyl si ruky ako Pilát (ZÁTUReCKÝ 2005: 210); mat' čisté

${ }^{42}$ О тождествах в других языках см. КузнецовА 2015: 70-71.

${ }^{43}$ Ср. с укр. мати Пєтра 'быть испуганным'; нагнати Петра; польск. nagnać (napędzić) Piotra - 'сильно испугать кого-л.' (Номис 1993: 593).

${ }^{44}$ Историки Библии указывают, что это не римский, а еврейский обычай, и высказывают сомнение, что римский прокуратор включил его в свою судебную процедуру. В то же время распятие - типично римская казнь, унаследованная от карфагенян и применяемая к рабам и политическим преступникам. 
ruky [ako Pilát] (SKLadaná 1993: 60); чеш. mýt si ruce jako [Pontský] Pilát (Pilát Pontský) (SČF 1983: 270); pус. умылть/умывать [свои] руки [как Пилат] (Михельсон 2: 418, ССРЯ 2003: 318); болг. измивам ръцете си от вина [като Пилат] (НБФР 2: 701); хорв. umite (prati/oprati) ruke [kao Pilat] (MАТЕŠIĆ 1982: 588); в.-луж. sej ruce myć/wumyć [kaž Pilatus] (IvČENKO-WöLKe 2004: 298); польск. итуwać, (реже) umyć ręce [jak Piłat] (SKоRUPKA 1: 679, ПРФС 2: 309). Негативную характеристику персонажа содержит и в.-луж. sudnik ['судья'] kaž Pilatus (САВКА 2002: 140).

Из сознания христиан нельзя было искоренить тот факт, что римский прокуратор мог предотвратить смерть Иисуса, ${ }^{45}$ но не сделал этого либо из трусости, так как Пилат предал Иисуса на распятие иудеям после угроз: «Если отпустишь его, ты не друг кесарю; всякий, делающий себя царем, противник кесарю» (Ин 19: 12), либо из других соображений. Своеобразным фразеологическим воплощением этого факта являются сравнения, содержащие намек на слова молитвы «Символ Веры» [т. е. «Кредо»]: «Распятаго же за ны при Понтийстем Пилате, и страдавша, и погребена» (Православный молитвослов, 19) и подчеркивающие неуместность упоминания в ней имени наместника Иудеи: слвц. dostat'sa niekam, do niečoho ako Pilát do kréda (SMIEŠKOVÁ 1974: 113); чеш. dostal se do toho (přijit) jako Pilát do Kreda (kreda, do Věřrm ${ }^{46}$ ) (ZAORÁLEK 2000: 508, 626; SČF 1983: 33); хорв. dospjeti kao Pilat u Vjerovanje ( и Kredo); naći kao Pilat u Vjerovanju (u Kredu) (MАтеŠı́́ 1982: 467); польск. dostać sięjak Piłat w Credo (kredo) (SKORUPKA 1: 679, KSJP 1996); włazt (wmieszat się) jak Piłat w credo (kredo, w credzie) (NKP 2: 930, KSJP 1996); кашуб. wmieszac se jak Pilôt w Kredo (RAмUŁт 1893: 134, 255); венг. belekerült (úgy került bele), mint Pilátus a krédóba (O. NAGY 1976: 558); нем. hineingeraten wie Pilatus ins Credo (НБФР 2: 152); er ist dazu gekommen wie Pilatus ins Credo; wie der Pontius ins Credo kommen (WALTER 2008: 232-233), а также польск. potrzebny jak Piłat w credo (w credzie) 'абсолютно не нужен' (NKP 2: 930); чеш. ten tam patři jako v Credo ( $v$ kredo) Pontský (pontský) Pilát 'ни к чему там, не относится к тому' (ZAORÁLEK 2000: 508, 626); нем. man gedenkt seiner wie des Pilatus im Credo 'поминают его как Пилата в Кредо' - т. е. поминать лихом (БHРC 2: 196); man gedenkt imds. wie des Pilatus im Credo (WALTER 2008: 231).

К сказаниям о воскресении Иисуса восходят рус. ирон. плакать (рыдать) как Магдалина ${ }^{47}$ 'сильно плакать, рыдать, выставляя свои чувства напоказ' (БЕТЕХтина 1999: 166); фр. pleurer comme une madeleine 'плакать как кающаяся Магдалина, горько плакать' (Огольцев 1972: 113). В коротком отрывке Иоанн четыре раза упоминает о плаче скорбящей о своем Учителе Марии Магдалины (Ин 20: 11-15), что не могло не укорениться в сознании хрис-

45 «Пилат говорит Ему: ...не знаешь ли, что я имею власть распять Тебя и власть имею отпустить Тебя?» (Ин 19: 10).

${ }^{46}$ Оборот prijít jako Pilát do kreda имеет также семантику 'быть несправедливо обвиненным в супружеской измене; иметь алиби' (SČF 1983: 33).

${ }^{47}$ Сравнение встречается в текстах начала XIX в.: «Как Магдалина плачешь ты, / И как русалка ты хохочешь!» (Е. А. Баратынский: К..., 1824-1825). 
тиан. Однако «оценка данного библейского образа в Священном писании и оценка фразеологизма не совпадают» (БЕтЕХтинА 1999: 98); в них актуализируется значение 'падшая женщина, осознавшая свою греховность': рус. каюшаяся (раскаявшаяся) Магдалина (Лилич 1996: 23); каяться как Магдалина; фр. Madeleine repentante 'кающаяся грешница' (Огольцев 1972: 113). Это связано с ошибочным отождествлением св. Марии Магдалины с грешницей из города Наина (Лилич 1996: 23), которая в порыве раскаяния «начала обливать ноги Его [Иисуса Христа - И. К.] слезами и отирать волосами головы своей, и целовала ноги Его, и мазала миром» в доме фарисея Симона (Лк 7: 37-50, Мк 14: 3-9), и с Марией, сестрой воскрешенного Иисусом Лазаря, сделавшей то же самое (Ин 12: 3). Словакам известно выражение tvárit' sa ako Mária Magdaléna 'притворяться' (MAтоl'́kové 2013), а венграм - néz, mint egy bünbánó Magdolna ${ }^{48}$ ['смотрит как кающаяся Магдалина']. Иногда же сравнение полностью утрачивает связь с исходным фразеологизмом: фр. suer (transpirer) comme une Madeleine ['обливаться потом как кающаяся Магдалина обливалась слезами']. На возникновение части оборотов с этим образом «большое влияние оказала традиция изображения Марии Магдалины в живописи с лицом, залитым слезами, и с глазами, обращенными к небу» (БЕТЕХТИНА 1999: 56).

Мотив чудесного зачатия и рождения Девой Марией Иисуса Христа от Духа Святого (Мф 1: 18-20, Лк 1: 26-35), навеянный евангелистам Ветхим Заветом - пророчеством Исаии (Ис 7: 14), лег в основу слвц. byt' nepoškvrnená ako Panenka Mária (SNK), хорв. čist kao blažena djevica Marija 'чистая, невинная' (Menac-Minalić 2003-2004: 368); рус. как непорочная Дева [Мария] ' 1 . о невинной, целомудренной и очень скромной девушке; 2. о целомудренном, чистом, невинном и простодушном человеке’ (ССРЯ 2003: 94), которые в разговорной речи часто приобретают оттенок иронии. С ее образом также связаны слвц. pekná ako Panenka Mária (SNK), хорв. lijepa kao djevica Marija 'очень красивая' (MENAC-MiнALIĆ 2003-2004: 369), а также слвц. tvárit' sa ako Panenka Mária 'притворяться добрым, непорочным'49 (MAтоLÁкоvé 2013).

Один из апостолов-учеников Христа усомнился в его Воскресении, откуда слвц. krúti hlavou ako neveriaci Tomáśs (САВКА 2002: 143); рус. устар. книжн. как Фома неверуюший (неверный) (SCFI 1983: 360); чеш. [být jako] nevěrici Tomáś (CzPS 1996: 262-263); хорв. диал. kak neverovani Toma; kaj neveruvoani Tumoaš; ka nevirni Toma (Menac-Minalić 2003-2004: 375-376); в.-луж. dwěler ['сомневающийся'] kaž Domaš (САВКА 2002: 142).

Как показывает материал, в целом символика библейских имен интернациональна, но далеко не все фразеологизмы библейского происхождения являются таковыми.

${ }^{48}$ Информант - Й. А. Балажи.

${ }^{49}$ В хорватском языке это же значение выражается фразеологизмами glumiti blaženu djevicu Mariju; misliti da je tko djevica Marija; praviti se djevica Marija (MenAC-MıHALIĆ 2003-2004: $368)$. 


\section{Литература}

Азимов-Толстой 1995 = Азимов А. Г., Толстой Н. И. Астрономия. В кн.: Славянские древности. Т. 1. Москва: «Международные отношения», 1995. 117-119.

БЕТЕХТИНА 1995 = БЕТЕХТИНА Е. Н. Фразеологические единицЫ с антропонимическим компонентом библейского происхождения в русском и английском языках. В кн.: Библия и возрождение духовной культуры русского и других славянских народов. К 80-летию Русской / Северо-Западной Библейской Комиссии (1915-1995). СанктПетербург: «Петрополис», 1995. 20-31.

БЕТЕХТИНА 1999 = БЕТЕХТИНА Е. Н. Фразеологизмы с библейскими именами. СанктПетербург: «Издательство Санкт-Петербургского университета», 1999.

БиРих 1998 = ВIERICH А. К сопоставительно-историческому изучению структурносемантических моделей в чешской, русской, хорватской и сербской фразеологии. В кн.: Историко-этимологическое изучение славянских фразеологических систем. Санкт-Петербург: «Конвенция», 1998. 15-34.

БМС 1997 = БИРИХ А. К., МОКИЕНКО В. М., СТЕПАНОВА Л. И. Словарь фразеологических синонимов русского языка. Ростов-на-Дону: «Феникс», 1997.

БНРС = Большой немецко-русский словарь. Т. 1-2. Москва: «Русский язык», 1980.

БРФС 1974 = Болгарско-русский фразеологический словарь / Българско-руски фразеологичен речник. Москва: «Русский язык», София: «Наука и изкуство», 1974.

ВАРХОЛ-ІВЧЕНКО 1990 = ВАРХОЛ Н., ІВЧЕНКО А. Фразеологічний словник лемківських говірок Східної Словаччини. Братіслава: «Словацьке педагогічне видавництво»; Пряшев: «Відділ української літератури», 1990.

ВОРОБЬЕВА 2009 = ВОРОБЬЕВА Л. Б. Фразеология как источник лингвокультурологического материала при изучении русского языка как иностранного. В кн.: Фразеологизм в тексте и текст во фразеологии. Четвертые Жуковские чтения. Великий Новгород: «НовГу им. Ярослава Мудрого», 2009. 245-247.

Гром 2004 = Гром Г. Франкові Нагуєвичі. Дрогобич: «Відродження», 2004.

Даль = Даль В. И. Толковый словарь живого великорусского языка. Т. 1-4. Москва: «Прогресс», «Универс», 1994.

ДоБРОВОльский 1894 = ДоБРОВОльский В. Н. Смоленский этнографический сборник. Ч. 3. Пословииы. Санкт-Петербург, 1894.

ДоБРОЛЬОЖА 2003 = ДоБРОЛЬОЖА Г. Красне слово - як золотий ключ. Постіні народні порівняння в говірках Середнього Полісся та суміжних територій. Житомир: «Волинь», 2003.

ЕрмолА 2011 = ЕрмолА В. И. Кашубско-русский фразеологический словарь. СанктПетербург: «Польский институт», 2011.

Івченко 1999 = Івченко А. Біблійна фразеологія верхньолужицкої мови. В кн.: Питання сорабістики. Львів: «Видавничий центр ЛНУ імені Івана Франка», 1999. 190-196.

КРАВцОВА 1981 = КРАВЦОВА С. И. Фразеологические единицы со значением количества в русском языке (в сопоставлении с украинскими). АКД. Ростов-на-Дону, 1981.

КСБФ 1997 = КОчЕДЫКОВ Л. Г., ЖиЛЬцОВА Л. В. Краткий словарь библейских фразеологизмов. http://www.bible-center.ru/dict/phrases.

КУЗНЕцОВА 1995 = КУзНЕцОВА И. В. Устойчивые сравнения русского языка (в сопоставлении с украинскими и сербохорватскими). Диссертация кандидата филологических наук. Санкт-Петербург, 1995. 
КУЗНЕЦОВА $2000=$ КУЗНЕЦОВА И. В. Иисус Христос, апостол Петр и Иуда в устойчивых сравнениях славян. В кн.: Проблемы региональной ономастики. Материальь 2-й межвузовской научно-практической конферениии. Майкоп: «Адыгейский государственный университет», 2000. 143-147.

КузНЕцОВА 2012 = КузНЕцОВА И. В. Адам и Ева в устойчивых сравнениях славян. Studia Slavica Hung. 57 (2012): 127-141.

КУЗНЕЦОВА 2014 = КУЗНЕЦОВА И. В. Языковая игра в библейской фразеологии разных языков. Studia Slavica Hung. 59 (2014): 337-351.

КУЗНЕцОВА 2015 = КУзНЕцОВА И. В. Иисус Христос в устойчивых сравнениях христиан. Studia Slavica Hung. 60 (2015): 65-78.

Кунин 1984 = Кунин А. В. Англо-русский фразеологический словарь. Москва: «Русский язык», 1984.

КЮВЛИЕВА-МИШАЙКОВА 1986 = КЮВЛИЕВА-МИШАЙКОВА В. Устойчивите сравнения в българския език. София: «Издателство на българската академия на науките», 1986.

ЛЕПЕШАЎ = ЛЕПЕШАЎ І. Я. Фразеалагічны слоўнік беларускай мовы. Т. 1-2. Мінск: «Беларуска энцыклапедыя», 1993.

Лилич 1996 = Лилич Г. А. Нетипичные мотивации библеизмов. В кн.: Frazeologia a religia. Tezy referatów międzynarodowego sympozjum naukowego. Opole, 4-6 września 1996 r. Opole: PRO, 1996. 23-24.

МасловА 2001 = МАсловА В. А. Лингвокультурология. Москва: «Академия», 2001.

МихеЛЬСОН = МихеЛЬСон М. И. Русская мысль и речь. Свое и чужое. Опыт русской фразеологии. Сборник образных слов и иносказаний. Т. 1-2. Москва: «Терра», 1994.

МЛТ 2010 = МокиЕнко В. М., Лилич Г. А., ТРОФимкинА О. И. Толковый словарь библейских выражений и слов. Москва: «АСТ», «Астрель», 2010.

Мокиенко 1989 = МокиЕнко В. М. Славянская фразеология. Москва: «Высшая школа», 1989.

Мокиенко 1998 = МокиЕнко В. М. Адам в славянских языках. В кн.: Число. Язык. Текст. Сборник статей к 70-летию Адама Евгеньевича Супруна. Минск: «Белгосуниверситет», 1998. 14-28.

МокиЕНКо-НикитинА 2008 = МокиЕнко В. М., НикитинА Т. Г. Большой словарь русских народных сравнений. Москва: «ОЛМА Медиа Групп», 2008.

НБФР = НикОЛОВА-ГълъБОВА Ж. Немско-български фразеологичен речник. Т. 1-2. Пловдив: «Летера», 2001.

НКРЯ = Нацииональный корпус русского языка. http://www.ruscorpora.ru.

Номис 1993 = Номис М. (ред.) Українські приказки, прислів'я і таке інше. Київ: «Либідь», 1993.

НУФС = Німецько-украӥнський фразеологічний словник. Т. 1-2. Київ: «Радянська школа», 1981.

ОГОльцЕВ 1972 = ОгольцЕВ В. М. Компаративные фразеологизмы русского языка в сопоставлении с французскими. В кн.: Вопросы семантики фразеологических единии славянских, германских и романских языков. Ч. 2. Новгород: «Издательство Новгородского государственного университета», 1972. 112-122.

ОГОЛЬЦЕВ 2001 = ОГОЛЬЦЕВ В. М. Словарь устойчивых сравнений русского языка (синонимо-антонимический). Москва: «Русские словари», «АСТ», «Астрель», 2001.

ППРН 1996 = Зимин В. И., СпиРин А. С. Пословицы и поговорки русского народа. Москва: «Сюита», 1996. 
ПРФС = Гюлумянц К. Польско-русский фразеологический словарь. Т. 1-2. Минск: «Экономпресс», 2004.

РодионовА $2004=$ РодионовА И. В. Дериваты библейских антропонимов в народной языковой традиции. Вопросы ономастики 1 (2004): 121-144.

РСХКЈ = Речник српскохрватскога књижевног језика. Т. 1-6. Нови Сад: «Матица српска», Загреб: «Матица хрватска», 1967-1976.

РСХС 1988 = Русско-сербохорватский словарь / Руско-српскохрватски речник. Москва: «Русский язык», Нови Сад: «Матица српска», 1988.

САВКА 2002 = САВКА О. Фразеологія серболужицької, словацької та української мов з біблійним ономастичним компонентом. Lětopis. Časopis za rěč, stawizny a kulturu Łužiskich Serbow 2002/1: 131-147.

СБГ = Слоўнік беларускіх гаворак паўночна-заходняй Беларусі і яе пагранічча. Т. 1-5. Мінск: «Навука і тэхніка», 1979-1986.

СБНП 2011 = Слоўнік беларускіх народных параўнанняў. Мінск: «Беларуская навука», 2011.

СЕЛИвеРСтовА 2013 = СеливеРСтова Е. И. [рец. на:] Harry Walter, Petra Fojtů: Schwarzes Schaf, falscher Prophet, barmherziger Samariter. Deutsch-tschechisches Wörterbuch biblischer Phraseologismen mit historisch-etymologischen Kommentaren. Greifswald, 2012. В кн.: Nationales und Internationales in der slawischen Phraseologie / Национальное и интернациональное в славянской фразеологии. Greifswald: Ernst Moritz Arndt Universität, 2013. 235-237.

СКЛАДАНА 1995 = СКЛАДАНА Я. Frazémy krest'anského pôvodu v minulosti a v súčasnosti. В кн.: Функционирование фразеологии в тексте в периоды кризиса идеологии и культуры. Тезисы докладов. Оломоуц, 1995. 66-67.

СОГ 1989 = Словарь орловских говоров. Вып. 1. Ярославль: «Издательство Ярославского государственного педагогического института», 1989.

СРНГ = Словарь русских народных говоров. Вып. 1-48. Москва-Ленинград-СанктПетербург: «Наука», 1965-2015.

ССРЯ 2003 = МокиЕнко В. М. Словарь сравнений русского языка. Санкт-Петербург: «Норинт», 2003.

СТЕПАНОВА 1985 = СТЕПАНОВА Л. И. Фразеологические единицы с именами собственными (на материале чешского языка). Диссертация кандидата филологических наук. Ленинград, 1985.

СУМ = Словарь української мови. Т. 1. Упор. Борис Грінченко. Київ, 1907.

СФС 1988 = КОЛОМІєЦь Н. Ф., РЕГУшЕВСьКИй Е. С. Словник фразеологічних синонімів. Київ: «Радянська школа», 1988.

Тимошик 2007 = Тимошик Г. Біблієконотоніми сучасної української мови у лінгводидактичному аспекті. Теорія і практика викладання української мови як іноземної. Вип. 2. Львів, 2007. 103-110.

ТуРКИНА-СТРОГОВА 1989 = ТУРКИНА Р. В., СтРОГОВА В. П. Лексико-семантическая система говоров Калининской области. Калинин: «Калининский государственный университет», 1989.

УРФС 1978 = Украӥнсько-російський і російсько-украӥнський фразеологічний словник/ Украинско-русский и русско-украинский фразеологический словарь. Київ: «Радянська школа», 1978.

ФРБЕ = НИЧЕВА К., СПАСОВА-МИХАЙЛОВА С., ЧОЛАКОВА Кр. Фразеологичен речник на български език. Т. 1-2. София: «Издателство на българската академия на науките», 1974-1975. 
ФСРЯ 1986 = Молотков А. И. (ред.) Фразеологический словарь русского языка. Москва: «Русский язык», 1986.

ЮрЧАНКА 1977 = ЮрЧАНКА Г. Ф. Слова за слова. Устойлівыя словазлучэнні ў гаворках Мсціслауцччыны. Мінск: «Навука і тэхніка», 1977.

ЮрченКО-ІвченКО 1993 = ЮрченкО О. С., ІвченКО А. О. Словник стійких народних порівнянь. Харків: «Основа», 1993.

Янкоўскі 1973 = Янкоўскі Ф. М. Беларускія народныя параўнанні. Кароткі слоўнік. Мінск: «Вышэйшая школа», 1973.

Bogović 1999 = Bogović S. Frazeologija ikavsko-ekavskoga mjesnoga govora Drage. Fluminensia 1999/1-2: 143-163.

CzPS 1996 = ORŁoś T. Z., HoRNIK J. Czesko-polski słownik skrzydlatych słów. Kraków: Universitas, 1996.

DRW 2009 = WALTER H., MOKIENKO V. Deutsch-russisches Wörterbuch biblischer Phraseologismen. Mit historisch-etymologischen Kommentaren. Greifswald: Philosophische Fakultät Ernst-Moritz-Arndt-Universität, 2009.

Federowski 1935 = Federowski M. Lud Bialoruski na Rusi Litewskiej. T. 4. Warszawa: Towarzystwo Naukowe Warszawśkie, 1935.

FINK 2006 = FINK ARSOVSKI Ž. Hrvatsko-slavenski rječnik poredbenih frazema. Zagreb: Knjegra, 2006.

FS 1996 = HABOVŠTIAKOVÁ K., KROŠLÁKOvÁ E. Frazeologický slovník. Človek a príroda vo frazeológii. Bratislava: Veda, 1996.

GIANITSOVÁ 2000 = GiANITSOVÁ Lucia: Náčrt problematiky frazeologizmov z biblických prameňov s výberovým slovníkom. Seminárna práca. Prešov: FF PU, 2000.

HFR 2003 = MENAC A., FINK-ARSOvski Ž., VENTURIN R. Hrvatski frazeološki rječnik. Zagreb: Naklada Ljevak, 2003.

IVČENKO-WÖLKE 2004 = IVČENKO A., WÖLKE S. Hornjoserbski frazeologiski słownik Obersorbisches phraseologisches Wörterbuch - Верхнелужиикий фразеологический словарь. Budyšin/ Bautzen: Ludowe nakładnistwo Domowina, 2004.

KOMORNICKA 1994 = KOMORNICKA A. M. Stownik zwrotów i aluzji biblijnych. Łódź: Archidiecezjalne Wydawnictwo Łódźkie, 1994.

KRAJEWSKI 1993 = KRAJEWSKI L. Porownania z antroponimicznym komponentem. In: Onomastyka literacka. (Studia i Materiały. Wyższa Szkoła Pedagogiczna w Olsztynie. Filologia Polska 53.) Olsztyn: WSP, 1993. 385-392.

KRZYŻANOWSKI = KRZYŻANOWSKI J. Mądrej głowie dość dwie stowie. T. 1-3. Warszawa: Państowy Institut Wydawniczy, 1975.

KSJP 1996 = Komputorowy słownik języka polskiego. Warszawa: PWN, 1996.

KSSJ 2003 = Krátky slovník slovenského jazyka. Bratislava: Veda, 2003.

LÁSZlovÁ 1997 = LÁSzLOVÁ Karin: Vyzliekanie z kože. Bratislava: PTK Echo Slovakia, 1997.

LÁSZLOVÁ 2004 = LÁSZLOvÁ Karin: Stopami vašich zážitkov. Ružomberok: Epos, 2004.

ŁĘGA 1933 = ŁĘGA W. Ziemia Malborska. Kultura ludowa. Toruń: Wydawnictwa Institutu Bałtyckiego, 1933.

LORENTZ = LORENTZ F. Pomoranische Wörterbuch. Bd. 1-5. Berlin: Verlag der Akademie der Wissenschaften, 1958-1983.

MATEŠIĆ 1978 = MATEŠIĆ J. O poredbenom frazemu u hrvatskom jeziku. Filologija 8. Zagreb, 1978. 211-217.

MATEŠIĆ 1982 = MATEŠIĆ J. Frazeološki rječnik hrvatskog ili srpskog jezika. Zagreb: Školska knjiga, 1982. 
MATOLÁKOVÁ 2013 = MATOLÁKOVÁ A. Prekladová realizácia frazeologických jednotiek v biblických translátoch 1. Morfologicko-syntaktické posuny. Jazyk a Kultúra 15. Prešov, 2013. http://www.ff.unipo.sk/jak/cislo16.html.

Menac 1973 = Menac A. Posuđeni elementi u ruskoj i hrvatskoj frazeologiji. In: Pranjić Krunoslav (ured.): Zbornik radova posvećen VII. međunarodnom kongresu slavista $u$ Varšavi. Zagreb: Hrvatsko filološko društvo, 1973. 89-99.

MenAC 1983 = MENAC A. Tipovi genitivnih sveza u frazeologizmima suvremenog ruskog i hrvatskog književnog jezika. In: MENAC A. (ured.) Хорватскосербско-русские контрастивные исследования / Hrvatskosrpsko-ruske kontrastivne studije 2. Iz kontrastivne problematike. Zagreb: Filozofski fakultet Sveučilišta u Zagrebu, 1983. 1-28.

MENAC 2001 = MENAC A. Načini klasifikacije frazeologije tujega jezika pri univerzitetnem študiju. In: KRŽIŠNIK E. (ured.): Skripta 5. Zbornik za učitelje slovenščine kot drugega / tujega jezika. Ljubljana: Center za slovenščino kot drugi/tuji jezik pri Oddelku za slovanske jezike in književnosti Filozofske fakultete v Ljubljani, 2001. 65-73.

Menac-Minalić 2003-2004 = MenaC-Minalić M. Hrvatski dijalektni frazemi s antroponimom kao sastavnicom. Folia Onomastica Chroatica 12-13 (2003-2004): 361-385.

MenaC-Mihalić 2005 = MenaC-Minalić M. Iz frazeologije novoštokavskih ikavskih govora južne Hrvatske. In: PrAnjKović I. (ured.) Od fonetike do etike. Zbornik o sedamdesetogodišnjici prof. dr. Josipa Silića. Zagreb: Disput, 2005. 309-324.

Menac-Minalić 2011 = MenaC-Minalić M. Iz kajkavske frazeologije. Rasprave Instituta za hrvatski jezik i jezikoslovlje 37. Zagreb, 2011. 479-491.

MLACEK 2007 = MlaceK J. Štúdie a state o frazeológii. Ružomberok: Filozofická fakulta Katolíckej univerzity v Ružomberku, 2007.

MoKIENKO-WURM 2002 = MOKIENKO V., WuRM A. Česko-ruský frazeologický slovník. Olomouc: Vyd. Univerzita Palackého, 2002.

NKP = KRZYŻANOWSKI J. (red.) Nowa księga przysłów $i$ wyrażeń przysłowiowych polskich . T. 1-4. Warszawa: Państowy Institut Wydawniczy, 1969-1978.

O. NAGY 1976 = O. NAGY Gábor: Magyar szólások és közmondások. Budapest: Gondolat, 1976.

PAVliCA 1960 = PAVliCA J. Frazeološki slovar v petih jezikih. Rečnik slovenačkih, hrvatskosrpskih, latinskih, njemačkih i engelskih fraza. Ljubljana: DZS, 1960.

RADYSERB-WJELA 1902 = RADYSERB-WJELA J. Přistowa a přistowne hrónčka a wustowa Hornjotužiskich Serbow. Budyšin: Smolerjec serbskeje knihičiščernje, 1902.

RAdYSERB-WJEla 1905 = RAdYSERB-WJela J. Metaforiske Hrona abo Přenoški a Přirunanki v rěči Hornjołužiskich Serbow. Budyšin: Smolerjec serbskeje knihičiščernje, 1905.

RAGUŽ 1979 = RAGUŽ D. Vlastita imena u frazeologiji. Onomastica Jugoslavica 8. Zagreb, 1979. 17-23.

RAMUŁT 1893 = RAMUŁT S. Stownikjęzyka pomorskiego czyli kaszubskiego. Kraków: Wydawnictwo Akademii Umiejętności, 1893.

RIBAROVA 2001 = RIBAROVA S. Frazemi s biblijskim osobnim imenima u češkom i hrvatskom jeziku. Riječ. Časopis za slavensku filologiju 2001/1: 71-76.

RÖHRICH = RÖHRICH L. Lexikon der sprichwörtlichen Redensarten. Bd. 1-4. FreiburgBasel-Wien: Herder, 1973.

RSFS 1998 = Dorotjaková V., Ďurčo P., Filkusová M., Petrufová M., Malíková M. O. Rusko-slovenský frazeologický slovník. Bratislava: SPN, 1998.

Ruiz-Zorilla CRUZATE 1996 = RuIZ-Zorilla CRUZATE M. Библеизмы в русско-каталонском сопоставлении. In: Frazeologia a religia. Tezy referatów międzynarodowego sympozjum naukowego. Opole, 4-6 września 1996 r. Opole: PRO, 1996. 125-127. 
SČF 1983 = Slovník české frazeologie a idiomatiky. Přirovnání. Praha: Academia, 1983.

SKLADANÁ 1993 = SKLADANÁ J. Frazeologický fond slovenčiny v predspisovnom období. Bratislava: Veda, 1993.

SKLADANÁ 1999 = SKLADANÁ J. Slová z hlbín dávnych vekov. Bratislava: Grand Multitrade, 1999.

SKORUPKA = SKORUPKA S. Stownik frazeologiczny języka polskiego. T. 1-2. Warszawa: Wiedza Powszechna, 1967-1968.

SMIEŠKOvÁ 1974 = SMIEŠKOvÁ E. Malý frazeologický slovník. Bratislava: Slovenské pedagogické nakladatel'stvo, 1974.

$\mathrm{SNK}=$ Slovenský národný korpus. http://korpus.sk.

SS 2006 = Slovo o slove 12. Zborník Katedry komunikačnej a literárnej výchovy Pedagogickej fakulty Prešovskej univerzity. Prešov: Prešovská univerzita, 2006.

SSN 1994 = RIPKA I. (red.) Slovník slovenských náreči. T. 1. Bratislava: Veda, 1994.

TREDER 1989 = TREDER J. Frazeologia kaszubska a wierzenia i zwyczaje (na tle porównawczym). Wejherowo: Muzeum Piśmiennictwa i Muzyki Kaszubsko-Pomorskiej, 1989.

VARŁYHA 1970 = VARŁYHA A. Krajovy stoŭnik Łahojščyny. New Jork: Vydańnie Zaranka, 1970.

VöÖ 1999 = VöÖ Gabriella: Szaván fogjuk. Erdélyi magyar szólások. Székelyudvarhely: Erdélyi Gondolat, 1999.

VRANIĆ 2005 = VRANIĆ S. Iz kostrenske frazeologije. In: VRANIĆ S. (ured.) Zbornik Čakavskoga sabora Kostrena. Život, kultura i povijest Kostrene. Knj. 1. Kostrena: Katedra Čakavskoga sabora Kostrene, 2005. 139-152.

VSRS = Vel'ký slovensko-ruský slovník. T. 1-6. Bratislava: Veda, 1979-1995.

WALTER 2008 = WALTER H. Wörterbuch deutscher sprichwörtlicher und phraseologischer Vergleiche. Teil 1. Hamburg: Dr. Kovač, 2008.

WW 1982 = Wörter und Wendungen. Wörterbuch zum deutschen Sprachgebrauch. Leipzig: VEB Bibliographisches Institut, 1982.

ZAORÁleK 2000 = ZAORÁLeK J. Lidová rčení. Praha: Academia, 2000.

ZÁtURECKÝ 2005 = ZÁTURECKÝ A. P. Slovenské prislovia, porekadlá, úslovia a hádanky. Bratislava: Slovenský Tatran, 2005. 